\title{
APSKATI
}

http://doi.org/10.22364/adz.56.16

\section{LATVIJAS EMIGRANTU KOPIENAS - LATVIJAS ZINĀTNIEKU PIENESUMS STARPTAUTISKĀS MIGRĀCIJAS PĒTNIEKIEM}

Baiba Bela, Dr. sc. soc., LU Sociālo zinātņu fakultātes

asociētā profesore un vadošā pētniece

The Emigrant Communities of Latvia: National Identity, Transnational Belonging, and Diaspora Politics (Latvijas emigrantu kopienas: nacionālā identitāte, transnacionālā piederība un diasporas politika) - ar šādu nosaukumu 2019. gadā Springer izdevniecība IMISCOE grāmatu sērijā ir laidusi klajā LU Filozofijas un sociologijas institūta pētnieku kolektīvo monogrāfiju. Grāmatas zinātniskās redaktores ir Rita Kaša un Inta Mieriņa. Grāmata tapusi, balstoties uz 2014. un 2015. gadā veikto tāda paša nosaukuma ESF finansēto pētījumu, kura rezultāti plaši pieejami mājaslapā Migracija.lv un latviski izdotajā grāmatā Latvijas emigrantu kopienas: cerību diaspora (Mierina 2015).

Pirms pievēršos grāmatas satura aplūkojumam, vispirms jāsaka daži vārdi par to, kāpēc sociālajās zinātnēs Latvijā šì grāmata ir patiešām liels notikums. Pirmkārt, Springer ir viena no nozīmīgajām zinātnes izdevniecībām Eiropā. Tā publicē grāmatas, žurnālus un konferenču rakstu krājumus vairāk nekā 20 zinātņu nozarēs. Otrkārt, IMISCOE ir nozīmīgākais starptautiskās migrācijas un dažādības izpētes izcilības tīkls. IMISCOE grāmatu sērija ir veltīta empīriskiem un teorētiskiem ārējās migrācijas jautājumiem, sērijas redkolēgiju veido vadošie jomas speciālisti Eiropā, un tās akadēmiskie standarti ir l,oti augsti. Līdz šim sērijā ir izdots tikai mazliet vairāk nekā 80 grāmatu, un samērā reti tās pievēršas vienas valsts vai vienas etniskas grupas migrācijas pieredzei. Lielākoties tiek aplūkotas tādas tēmas kā migrācijas un integrācijas politika Eiropā, etniskā dažādība ES valstīs un pilsētās, pilsonība un migrācija, patvēruma meklētāju problemātika, migrācija un sociālās drošības jautājumi, darba tirgus globalizētā pasaulē, migrācijas ietekme uz ǵimenēm un bērniem u. tml. Migrācijas pētnieki no Latvijas šajā sērijā ir bijuši grāmatu nodaḷu autori vai līdzautori (piem., Mihails Hazans, Inta Mieringa, Aija Lulle). Bet pirmo reizi šajā prestižajā grāmatu sērijā ir izdevums, kas pilnībā veltìts tikai Latvijas diasporas tēmai un ko veidojuši tikai mūsu zemes zinātnieki (arī diasporā dzīvojošie), Eiropas zinātnes telpā aktualizējot Latvijas migrācijas jautājumus un paceḷot mūsu valsts pētnieku darbu pilnīgi citā redzamības un atpazīstamības līmenī.

Kaut abām grāmatām nosaukumi sākas identiski, atškirīibas nav tikai apakšvirsrakstu formulējumos. Grāmatas Latvijas emigrantu kopienas angḷ izdevums ir veidots starptautiskās migrācijas pētniekiem (ievads uzrunā tieši šo auditoriju), mazliet atškiras grāmatu struktūra, 
autoru kolektīvs, klāt nākušas dažas jaunas nodaḷas, savukārt dažas izdevumā angḷu valodā nav iekḷautas. Grāmatas zinātniskās redaktores R. Kaša un I. Mieriņa ievadā aplūko emigrācijas aktualitāti Latvijā, parāda šī pētìjuma novitāti un pienesumu zināšanām par migrācijas procesiem Eiropā un norāda uz jautājumiem, kas raksturīgi jebkurai migrācijas pieredzei, ne tikai Latvijas emigrantiem (piem., bērnu straujā asimilācija mītnes zemē). Pētnieces uzsver, ka līdz šim galvenā uzmanība austrumeiropiešu migrācijā uz Rietumeiropu pievērsta darbaspēka kustībai (galvenokārt emigrantu nodarbinātībai), kamēr šis darbs sniedz dziḷāku izpratni arī par citiem ar izceḷošanu saistītiem jautājumiem - emigrantu sociālo un politisko uzticēšanos, emigrantu sociālo tîklošanos un sociālo iekḷaušanos, par viņu identitāti un piederības izjūtu, valodas lietošanu un apgūšanu bērniem, emigrantu pilsonisko līdzdalību mìtnes un izcelsmes zemēs, attālināto nacionālismu un diasporas politiku. Tiek aplūkoti ar̄ī tādi jebkurai migrācijai būtiski jautājumi kā emigrantu iesakṇotība mītnes zemē, attiecības ar izcelsmes zemes kultūru un sabiedrību, kā arī attiecības starp izceḷotājiem no dažādiem emigrācijas viḷniem. Turklāt šis pētījums ir veikts migrantus nosūtošās valsts (sending country) perspektīvā, kamēr vairums pētījumu ir uzṇemošo valstu skatījumā. Grāmata l̦auj ielūkoties arī emigrācijas procesos no mazas valsts viedokḷ un sniedz padziḷinātu ieskatu baltiešu diasporas pieredzē, kamēr līdz šim saistībā ar Austrumeiropu plašāk ir pētītas salīdzinoši lielās poḷu un rumāṇu emigrantu kopienas.

Grāmatā angḷu valodā nodaḷas ir strukturētas pa trim lielām tēmām: 1) mūsdienu Latvijas migrācijas un izpētes metodolog̣ijas raksturojums; 2) migrantu transnacionālās un nacionālās piederības gadījumu analīze; 3) atgriešanās migrācija un sūtītājvalsts politika (kamēr izdevumā latviešu valodā nodaḷas izkārtotas piecos tematiskos blokos). Grāmatas ievads iepazīstina ar katras nodaḷas tematiku un nozīmīgākajiem secinājumiem. Latviešu izdevuma divus tematiskos blokus veidojošās nodaļas par pētījuma metodoloǵiju un darbaspēka migrāciju angḷu izdevumā ir konsolidētas, transformētas un jaunveidotas vienā tēmā.

I. Mieriņas nodaḷa par pētījuma integrēto pieeju emigrantu izpētē iepazīstina ārvalstu pētniekus ar pētījumā lietoto metodologiiju un starptautiski nozīmīgiem jauniem risinājumiem šajā pētījumā, kas būtu noderīgi arī emigrācijas pētniekiem citās valstīs. M. Hazans aplūko migrācijas vēsturi 20. gs. Latvijā un padziliināti pievēršas 2000.-2015. gada emigrācijas četriem viḷniem. Ilze Koroḷeva analizē vairāk nekā 14000 respondentu atbilžu, veidojot emigranta profilu saistībā ar viņa attieksmēm un pašidentifikāciju ar mītnes un izcelsmes zemi (šīs nodaļas latviešu izdevumā nav). N̦emot vērā, ka emigrācijai pamatā ir ekonomiski faktori, Aivars Tabuns analizē formālos un neformālos darbiekārtošanās procesus, kā ar̄̄ nevienlīdzīgo attieksmi un diskrimināciju, ko darba tirgū pieredz emigranti.

Angḷu izdevuma nākamā lielā tēma veltīta migrantu transnacionālās un nacionālās piederības gadījumu analīzei, kurā apvienoti divi tematiskie bloki no latviešu izdevuma, klāt nākot vienai jaunai nodaḷai (Daiga Kamerāde un Ieva Skubiņa analizē, kā vecāki uztver bērnu identitātes veidošanos Lielbritānijā). Uzmanība pievērsta Latvijas emigrantiem Lielbritānijā, Vācijā, Zviedrijā un ASV, aplūkojot piederības, identitātes un transnacionālisma izpausmes kā latviski, tā krieviski runājošo emigrantu vidū. Noslēdzošā grāmatas tēma ir saistīta ar atgriešanās jeb remigrācijas politiku, pievēršoties plaisai starp iecerētajiem politikas mērḳiem un reālo atgriešanās praksi, kā ar̄̄ sasaistei starp finansējuma avotiem studijām ārvalstīs, atgriežoties Latvijā.

Latviešu pētnieku darbs sniedz vispusīgu un starpdisciplināru skatījumu uz emigrācijas procesiem mūsdienu Latvijā. Tomēr kā zinātniecei man pietrūkst pamatojuma autoru izvēlei Latviju identificēt ar Austrumeiropu. Mums pašiem noteikti labāk patiktu tikt identificētiem ar Ziemel̦eiropu atbilstoši ANO un ES klasifikācijai (tiesa, salīdzinoši nesenai). Tomēr grāmata turpina plaši izplatīto tradīciju, "pieskaitot" mūs Austrumeiropai, ko mūsdienās vairāk saista ar Austrumu ortodoksālās baznīcas izplatības areāla valstīm. Bez paskaidrojuma nav saprotams, vai šì ir vecās klasifikācijas nekritiska atražošana (PSRS okupācijas dēḷ ilgstošu periodu piederējām Austrumu militārajam blokam, kādēl tikām pieskaitīti Austrumeiropai arī pēc neatkarības atgūšanas), uzmanības pievēršanas stratēgija 
(Austrumeiropa joprojām daudziem pētniekiem šķiet interesantāka un mazāk izpētīta par Rietumeiropu vai Ziemel̦eiropu), vai arī migrācijas izpētē šāda pieeja varētu būt pamatota ar to, ka mūsu ekonomiskā attīstība joprojām būtiski atpaliek no "vecās" Ziemel̦eiropas un arī migrācijas trajektorijas izpētes periodā drīzāk atbilst Austrumeiropas reǵiona tendencēm, nevis Ziemeleiropai.

Taču, neskatoties uz šo nelielo trūkumu, noslēgumā vēlos uzsvērt Latvijas pētnieku ieguldījumu starptautiskās migrācijas izpētē iegūt ticamus un reprezentatīvus datus par emigrantiem no vienas valsts ir ārkārtīgi grūts uzdevums ikvienam migrācijas pētniekam. Interneta aptauja, kurā izdevās sasniegt emigrantu pētîjumiem unikāli lielu respondentu skaitu - pētījumam derīgas anketas aizpildīja 14068 latvieši un Latvijas valstspiederīgie 118 valstīs, ir nozīmīgs starptautiska mēroga zinātnes veiksmes stāsts (ja vien par veiksmi drīkst saukt loti pārdomātu un mērḳtiecīgu darbu aptaujas plānošanā, īstenošanā un datu sagatavošanā analīzei). Grāmatā aprakstītā pētījuma metodoloǵija noteikti var sniegt citu valstu migrācijas pētniekiem loti būtiskas zināšanas par to, kā iegūt ticamus un reprezentatīvus datus, lietojot dažādas inovācijas dalībnieku rekrutācijai un atbiruma mazināšanai aptaujā, kā arī rūpīgi izstrādātu statistisko svaru dizainu reprezentativitātes nodrošināšanai. Tādēḷ ir liels gandarījums, ka Latvijas zinātnieku darba rezultāti starptautiskā zinātnes telpā ir pieejami ne tikai nozares žurnālos, bet arī starptautiskās migrācijas pētnieku izcilības tīkla grāmatu sērijā prestižā izdevniecībā izdotā grāmatā. Migrācijas dziḷākā izpratnē ieinteresētiem lasītājiem Latvijā varu ieteikt iepazīties ar abiem Latvijas emigrantu kopienas izdevumiem - gan latviešu, gan angḷu valodā. 